Brit. Heart f., 1969, 31, 435.

\title{
Association of Right Bundle-branch Block with Left Superior or Inferior Intraventricular Block
}

\section{Its Relation to Complete Heart Block and Adams-Stokes Syndrome}

\author{
HENRI KULBERTUS ${ }^{\star}$ AND PIERRE COLLIGNON* \\ From the Division of Cardiology, Department of Medical Clinics and Semeiology, University of Liège School of \\ Medicine, Liège, Belgium
}

In recent years, most authors (Lev, 1957; Grant, 1957; Uhley and Rivkin, 1959; Spach et al., 1963; Lev, 1964; Pryor and Blount, 1966; van Bogaert, 1967) have considered that the fibres of the left bundle-branch may be thought of as being arranged into superior and inferior divisions. If a lesion involves a sufficiently large number of fibres of one radiation, the sequence of excitation of the left ventricle is altered. The electrocardiographic patterns of the left superior intraventricular block (Grant, 1956; Pryor and Blount, 1966) and of the left inferior intraventricular block (Pryor and Blount, 1966) have been described.

Either of these two conduction disturbances may coexist with complete right bundle-branch block and can be properly diagnosed since right bundlebranch block does not alter the beginning of ventricular activation (Grishman and Scherlis, 1952; Sodi-Pallares et al., 1963; Pryor and Blount, 1966; Castellanos et al., 1966; Saltzman, Linn, and Pick, 1966).

The association of a left superior or inferior intraventricular block with a right bundle-branch block may be rationally considered as a hazardous condition, since, in such cases, the atrioventricular conduction theoretically relies on the integrity of only one division of the left bundle. Patients giving evidence of such an association might therefore be prone to complete atrioventricular block.

The purpose of the present paper is to report 16 patients whose electrocardiogram showed complete right bundle-branch block in association with either left superior or left inferior intraventricular

\footnotetext{
Received September 12, 1968.

$\star$ Aspirants du Fonds National Belge de la Recherche Scientifique.
}

block. They all progressively developed atrioventricular block accompanied by Adams-Stokes syndrome and had to be treated by internal pacemaker.

\section{Electrocardiographic Criteria}

First degree atrioventricular block was considered present when the $P-R$ interval, corrected for heart rate, was $0.21 \mathrm{sec}$. or longer.

Right bundle-branch block was diagnosed when the electrocardiogram showed: (1) a QRS duration of 0.12 sec. or more; (2) a delayed onset of intrinsicoid deflection in the right praecordial leads ( $0.09 \mathrm{sec}$. or more), with ventricular activation time of less than $0.06 \mathrm{sec}$. in V6 (Lenègre, 1957; Lepeschkin, 1964).

For the diagnosis of left superior and left inferior intraventricular block in the presence of right bundlebranch block, the vectors that occur within the first $60 \mathrm{msec}$. of QRS interval were analysed and the criteria proposed by Pryor and Blount (1966) were applied.

In left superior intraventricular block, activation travels initially through the inferior division, and finally spreads over the left anterior ventricular wall. The initial forces $(20 \mathrm{msec}$.) are oriented downward ( $\mathrm{r}$ wave in leads II, III, and aVF, and small q wave in aVL), and the $40-60 \mathrm{msec}$. vectors are oriented in a superior direction ( $-30^{\circ}$ or higher), causing left axis deviation (Fig.1).

In left inferior intraventricular block activation travels initially through the superior division and finally spreads over the left inferior ventricular wall. The initial vector $(20 \mathrm{msec}$ ) therefore starts upward (small q wave in leads II, III, aVF, and small $\mathrm{r}$ wave in lead aVL), and the $40-60 \mathrm{msec}$. vectors are oriented in an unusual downward direction. An inferior terminal vector may be normal in young people or in adults who are tall and slender. On the contrary, according to Pryor and Blount (1966), inferior terminal forces (around $+90^{\circ}$ ) should be considered as abnormal and indicative of 435 


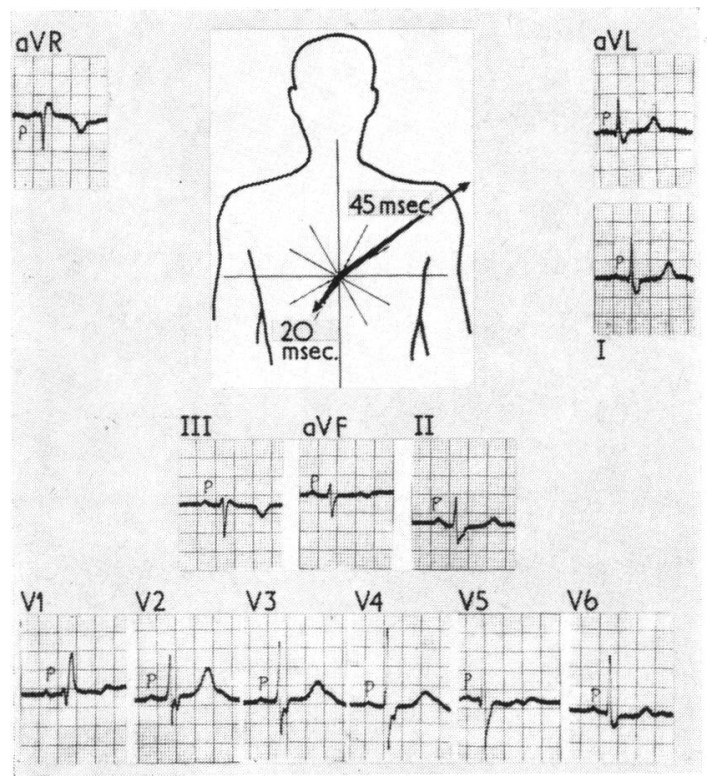

FIG. 1.-Orientation of the individual vectors occurring within the first $60 \mathrm{msec}$. in a case of left superior intraventricular block associated with right bundle-branch block.

years old or over and has a medium to heavy body build (especially if left ventricular hypertrophy is coexistent) (Fig. 2).

\section{DesCription OF CASES}

The electrocardiographic records of 76 patients with transient or permanent complete heart block have been reviewed. An electrocardiogram recorded before development of complete heart block or after recovery from transient block was available in 31 cases. In 16 instances ( 9 men, 7 women), a pattern of left superior or left inferior intraventricular block combined with right bundle-branch block was observed during supraventricular conduction. The ages of the latter patients range from 33 to 82 years, the average being 64 . The significant clinical and electrocardiographic findings are presented in the Table.

The association of left superior intraventricular block with right bundle-branch block was seen in 11 instances, and that of left inferior intraventricular block with right bundle-branch block in 5 .

In 6 patients (Cases 5, 10,11,13,15, and 16), despite a history of syncope and dizziness, the electrocardiograms recorded between the crises failed to display any evidence of atrioventricular conduction disturbance. Disclosure of left superior or inferior intraventricular block combined with right bundle-branch block initiated investigation to demonstrate transient complete heart block. This disorder was identified by repeated recordings or constant monitoring of the electrocardiogram by means of a magnetic tape-recorder.

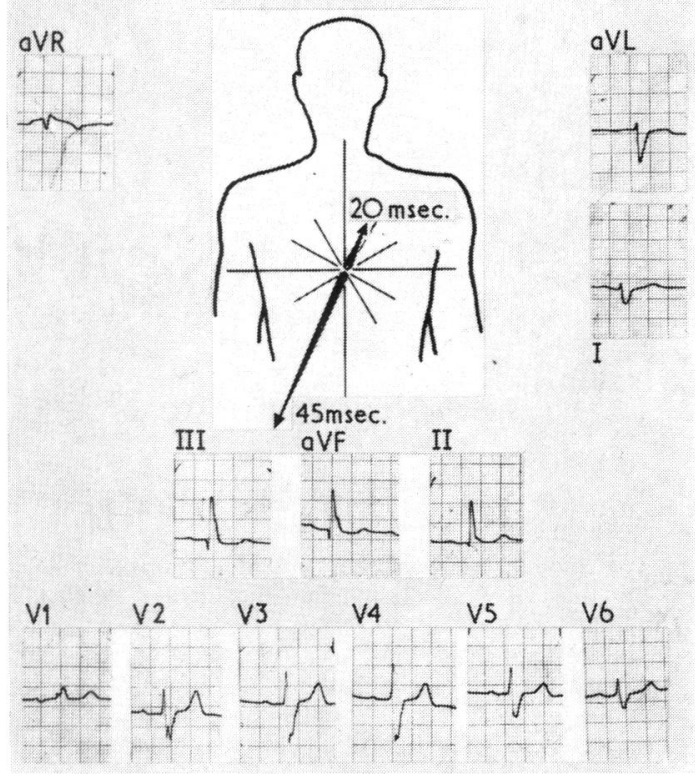

FIG. 2.-Orientation of the individual vectors occurring within the first $60 \mathrm{msec}$. in a case of left inferior intraventricular block associated with right bundle-branch block.

Age 68 years. Weight $93 \mathrm{~kg}$. (205 lb.), height $169 \mathrm{~cm}$.

In two patients, the separate components of the complete pattern, left superior intraventricular block with right bundle-branch block (Case 2), or left inferior intraventricular block with right bundle-branch block (Case 13), appeared successively. These two cases are illustrated in Fig. 3 and 4.

It should be noted that none of our patients had electrocardiographic evidence of myocardial infarction. Likewise, the onset of complete heart block never coincided with clinical signs suggesting acute coronary thrombosis.

\section{Discussion}

Several investigators have studied the association of complete right bundle-branch block with left axis deviation in cases of atherosclerotic heart disease (Lenègre, 1957; Lepeschkin, 1964; Saltzman et al., 1966; Lasser, Haft, and Friedberg, 1968) or after surgical closure of ventricular septal defects (Kulbertus, Coyne, and Hallidie-Smith, 1968). They have observed that this association is a frequent precursor of complete atrioventricular block (Lenègre, 1957; Lepeschkin, 1964; Saltzman et al., 1966; Slama et al., 1966; Lasser et al., 1968). They assume that the underlying conduction abnormality frequently is interruption of the right bundle-branch and of the superior subdivision of the left bundle. Recent experiments on canine 
TABLE

SUMMARY OF CLINICAL AND ELECTROCARDIOGRAPHIC DATA

\begin{tabular}{|c|c|c|c|c|}
\hline \multicolumn{3}{|c|}{$\begin{array}{l}\text { Case No., sex, and age (yr.) } \\
\text { when pacemaker was placed }\end{array}$} & Clinical data & \multirow[b]{2}{*}{ with Right Bundle-branch Block } \\
\hline \multicolumn{4}{|c|}{ A. Association of Left Superior Intraventricular Block with Right Bundle-branch Block } & \\
\hline 1 & $\mathbf{M}$ & 61 & $\begin{array}{l}\text { Peripheral vascular disease; hypertension; } \\
\text { giddiness and syncope since } 1961\end{array}$ & $\begin{array}{l}\text { 7. } 6.60: \text { LSIVB + RBBB } \\
\text { 11. } 6.61 \text { : Complete heart block }\end{array}$ \\
\hline 2 & $\mathbf{M}$ & 61 & $\begin{array}{l}\text { Atypical angina pectoris; } \\
\text { syncopal attacks since } 1962\end{array}$ & $\begin{array}{l}\text { 22.10.60: Normal ECG } \\
\text { 3.10.61: RBBB } \\
\text { 27. 4.62: LSIVB + RBBB with } 2: 1 \text { AV block } \\
\text { 20. 5.67: Complete AV block }\end{array}$ \\
\hline 3 & $\mathbf{F}$ & 82 & Adams-Stokes seizure in November 1964 & $\begin{array}{l}\text { 27.11.64: Complete AV block with short transient episodes } \\
\text { of 1st degree AV block with LSIVB-RBBB }\end{array}$ \\
\hline 4 & $\mathbf{F}$ & 80 & $\begin{array}{l}\text { Hypertension; Adams-Stokes seizure in } \\
\text { April } 1965\end{array}$ & $\begin{array}{l}\text { 20. 9.64: LBBB with } 2: 1 \text { AV block } \\
\text { 28. 4.65: LSIVB + RBBB with } 3: 1 \text { AV block with periods } \\
\text { of several seconds without any conducted beat }\end{array}$ \\
\hline 5 & $\mathbf{M}$ & 33 & $\begin{array}{l}\text { Congestive cardiomyopathy; } \\
\text { Adams-Stokes seizure since April } 1965\end{array}$ & $\begin{array}{l}\text { 2. 8.64: LSIVB + RBBB } \\
\text { 3. 9.65: Complete heart block }\end{array}$ \\
\hline 6 & $\mathbf{M}$ & 79 & $\begin{array}{l}\text { Angina pectoris; Adams-Stokes syndrome } \\
\text { with seizures since September } 1965\end{array}$ & $\begin{array}{l}\text { 28.10.65: LSIVB + RBBB with 2:1 AV block } \\
\text { 3.11.65: Complete AV block }\end{array}$ \\
\hline 7 & $\mathbf{M}$ & 73 & $\begin{array}{l}\text { Atypical angina; possible myocardial } \\
\text { infarct in October 1966; } \\
\text { Adams-Stokes seizures in January } 1966\end{array}$ & $\begin{array}{l}\text { 26.10.66: LBBB (with normal PR) } \\
\text { 25. 1.67: LSIVB-RBBB with 2nd degree AV block } \\
\text { 27. 1.67: Complete AV block }\end{array}$ \\
\hline 8 & $\mathbf{M}$ & 73 & $\begin{array}{l}\text { Atherosclerosis; congestive heart failure; } \\
\text { syncopal attacks since } 1965\end{array}$ & $\begin{array}{l}\text { 24.11.67: LSIVB-RBBB with } 2: 1 \mathrm{AV} \text { block } \\
\text { and episodes of complete AV block }\end{array}$ \\
\hline 9 & $\mathbf{F}$ & 64 & $\begin{array}{l}\text { Severe hypertension; angina pectoris; } \\
\text { syncopal attacks since November } 1966\end{array}$ & $\begin{array}{c}\text { 22. 1.67: Periods of 2:1 AV block with normal QRS } \\
\text { morphology alternating with periods of 1st } \\
\text { degree AV block with LSIVB-RBBB } \\
\text { 10.11.67: } 3: 1 \text { AV block with normal QRS morphology }\end{array}$ \\
\hline 10 & $M+$ & 71 & $\begin{array}{l}\text { Angina pectoris; syncope since } \\
\text { August } 1967\end{array}$ & $\begin{array}{l}\text { 28. 8.67: LSIVB-RBBB with transient episodes of } \\
\text { complete AV block (ventricular pauses of } \\
5 \text { to } 6 \text { sec.) }\end{array}$ \\
\hline 11 & $\mathrm{M}+$ & 70 & $\begin{array}{l}\text { Angina pectoris since } 1958 ; \\
\text { syncope since February } 1968\end{array}$ & $\begin{array}{l}\text { 22. 2.68: LSIVB-RBBB with transient episodes of } \\
\text { complete AV block }\end{array}$ \\
\hline \multicolumn{5}{|c|}{ B. Association of Left Inferior Intraventricular Block with Right Bundle-branch Block } \\
\hline 12 & $\mathbf{F}$ & 53 & Syncopal attacks since July 1964 & $\begin{array}{l}\text { 6. 8.64: LIIVB + RBBB with } 3: 1 \text { AV block } \\
\text { 12. 8.64: Complete AV block }\end{array}$ \\
\hline 13 & $\mathbf{F}$ & 68 & $\begin{array}{l}\text { Atherosclerosis; hypertension; } \\
\text { giddiness since September } 1965\end{array}$ & $\begin{array}{l}\text { 1.12.55: Normal ECG } \\
\text { 24. 7.58: LIIVB } \\
\text { 1. 6.65: LIIVB-RBBB } \\
\text { 1. 9.65: LIIVB-RBBB with transient episodes of } \\
\text { complete AV block } \\
\text { 1.12.65: Complete AV block }\end{array}$ \\
\hline 14 & $M$ & 64 & $\begin{array}{l}\text { Congestive heart failure and syncopal } \\
\text { attacks since June } 1965\end{array}$ & $\begin{array}{l}\text { 17. 6.65: LIIVB-RBBB with 2nd degree AV block } \\
\text { (Wenckebach's phenomenon) } \\
\text { 19. } 6.65: \text { LIIVB-RBBB with 2nd degree AV block } \\
\text { and long periods of complete AV block } \\
\text { without any ventricular activity }\end{array}$ \\
\hline 15 & $\mathbf{F}$ & 82 & $\begin{array}{l}\text { Adams-Stokes seizure in November 1967; } \\
\text { frequent giddiness since then }\end{array}$ & $\begin{array}{l}\text { 18. 2.68: LIIVB-RBBB; short periods of complete } \\
\text { AV block }\end{array}$ \\
\hline 16 & $\mathrm{Ft}$ & 73 & $\begin{array}{l}\text { Atherosclerosis; syncope since } \\
\text { February } 1968\end{array}$ & $\begin{array}{l}\text { 17. 6.67: LIIVB-RBBB } \\
\text { 4. 5.68: } 2: 1 \text { AV block } \\
\text { 7. } 5.68: \text { Complete AV block }\end{array}$ \\
\hline
\end{tabular}

* LSIVB, left superior intraventricular block; LIIVB, left inferior intraventricular block; LBBB, complete left bundlebranch block; RBBB, complete right bundle-branch block; AV block, atrioventricular block.

In the serial tracings, only those electrocardiograms showing a pattern different from the previous tracing were quoted.

† These patients were treated by internal demand pacemaker (Medtronic: 5841 ).

and primate hearts substantiate this assumption (Watt et al., 1968).

To our knowledge, the association of left inferior intraventricular block with right bundle-branch block, as a sign of bilateral bundle-branch conduc- tion disturbances which may lead to complete heart block, still remains undescribed. This is probably due to the fact that the clinical concept of left inferior intraventricular block has been only recently proposed by Pryor and Blount (1966). 


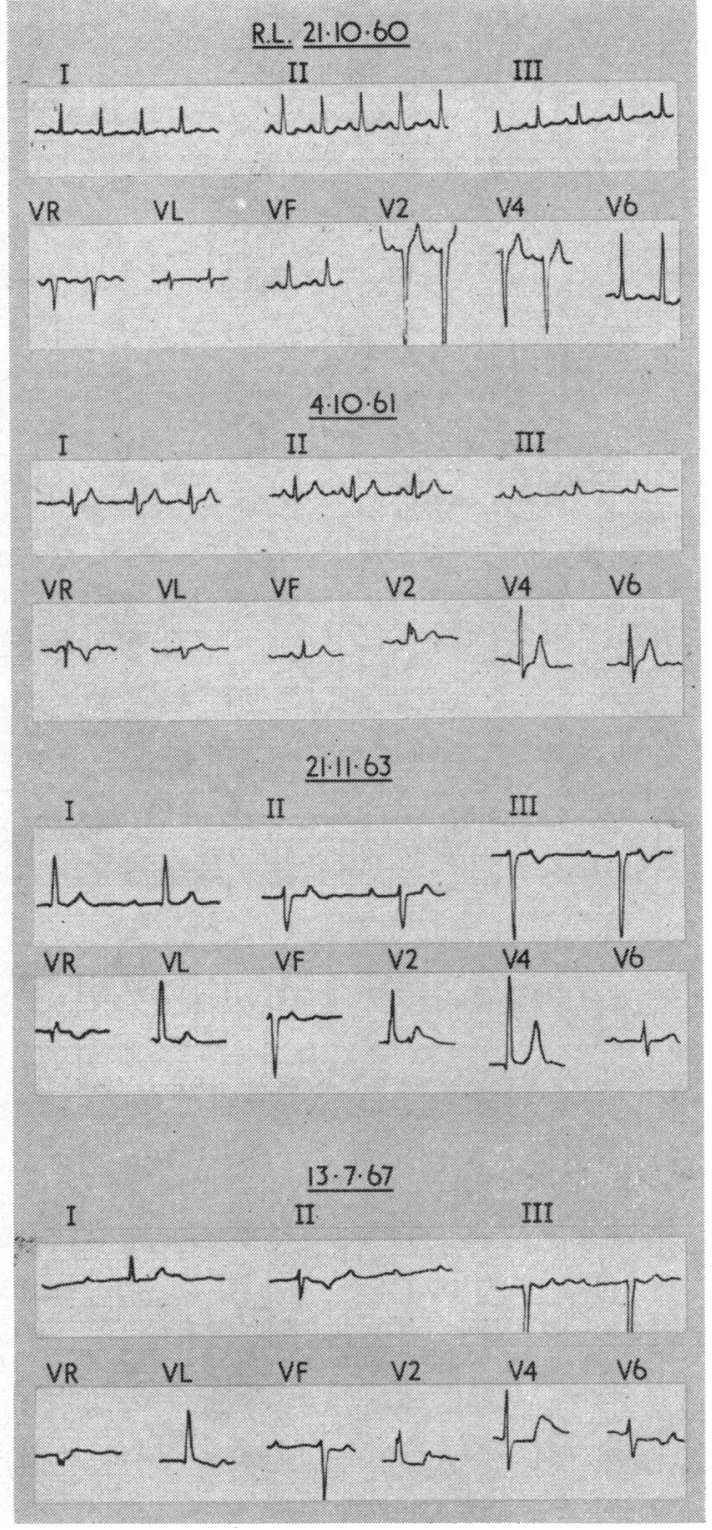

Fig. 3.-Progressive development of complete heart block in a patient (Case 2) whose tracings show the successive occurrence of right bundle-branch block alone, left superior intraventricular block with right bundle-branch block with 2:1 atrioventricular block, and complete heart block.

The concepts of these authors are mainly founded on experimental work which indicates that the terminal forces of the QRS complex are shifted inferiorly after laceration of the inferior division of the left bundle (Uhley and Rivkin, 1964; Watt and Pruitt, 1965). Moreover, the same authors
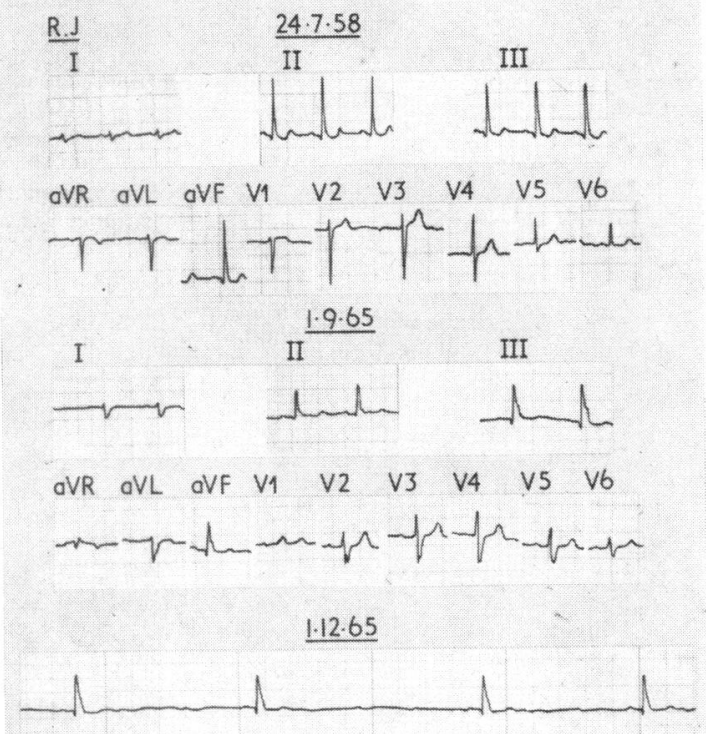

FIG. 4.-Progressive development of complete heart block in a patient (Case 13, same as in Fig. 2) whose successive tracings show left inferior intraventricular block alone, and associated with right bundle-branch block and advanced degree of atrioventricular block (lead III).

have reported two cases of clinical left inferior intraventricular block, examined at necropsy, whose conduction system upon histological examination revealed a fibrosis limited to the inferior radiation of the left bundle (Pryor and Blount, 1966).

Left inferior intraventricular block seems to be less frequent than left superior intraventricular block (van Bogaert, 1967). In addition, the anterior division of the left bundle-branch and the distal portion of the undivided right bundle-branch share a common blood supply provided by the septal branches of the left anterior descending coronary artery. The association of left superior intraventricular block with right bundle-branch block may therefore be expected to be more common than the association of left inferior intraventricular block with right bundle-branch block. This is in keeping with our findings which also indicate that the latter pattern bears the same consequences as the former: it may also represent a forerunner of complete atrioventricular block.

The histological lesions that can account for the patterns shown in these associations are not yet precisely known. Complete interruption of the right bundle-branch appears to have been consistently observed in all the cases hitherto reported (Unger et al., 1958; Lenègre, 1957; Lepeschkin, 1964). On the contrary, the lesions involving the 
left bundle fibres are of variable location and extent (Entman, Estes, and Hackel, 1967).

In his cases of type $\mathrm{Vb}$ right bundle-branch block, which meet the criteria for left superior intraventricular block combined with right bundle-branch block, Lepeschkin (1964) generally found but moderate involvement of the left bundle, and assumed that the left ventricular conduction disturbance was located in the ventricular wall itself or in only a small portion of the left bundle-branch. On the other hand, in Lenègre's extensive review (1957), one can find several cases in which the cardiographic tracings showed left superior or left inferior intraventricular block combined with right bundle-branch block and in which histological examination revealed complete interruption of the right bundle-branch and marked involvement of both radiations of the left bundle-branch. In the latter situation, the atrioventricular conduction relies on a very limited number of His fibres. The excitation is conducted to the ventricles through the radiation with the faster conduction, and one can speculate that any further lesion involving the specific conducting tissue might provoke complete heart block.

The diagnosis of such bilateral conduction disturbances is of considerable importance. They were disclosed in six of our patients who complained of syncope and dizziness, but whose initial electrocardiogram showed no sign of atrioventricular block. The diagnosis of Adams-Stokes syndrome was suspected and confirmed later by electrocardiographic demonstration of transient episodes of complete heart block. In our opinion, this kind of case represents one of the best indications for treatment by internal demand pacemakers and we have used this device for three patients in the present series.

\section{SUMMARY}

Sixteen patients are reported who had right bundle-branch block coexisting with either a left superior intraventricular block (11 cases) or a left inferior intraventricular block (5 cases). They progressively developed transient or permanent complete heart block with Adams-Stokes syndrome. Left superior intraventricular block as well as left inferior intraventricular block can be adequately diagnosed in the presence of complete right bundlebranch block. Criteria for diagnosis of these associations are described with special emphasis on left inferior intraventricular block combined with right bundle-branch block which, to our knowledge, still remains undescribed as a sign of bilateral branch conduction impairment leading to complete heart block.
It is concluded that early diagnosis of such bilateral branch conduction disturbances is of considerable importance. Their disclosure in elderly patients complaining of syncope or dizziness should prompt further investigations to try and demonstrate transient complete heart block. These cases represent a good indication for treatment by internal demand pacemakers.

We wish to thank Prof. A. Nizet and Dr. L. Humblet for their most constructive criticism. We also acknowledge the help of Mrs. B. Vervier and Miss S. Smeets, for secretarial and technical assistance.

\section{REFERENCES}

Castellanos, A., Lemberg, L., Ioannides, G., and Salhanick, L. (1966). The vectorcardiogram in right bundle branch block coexisting with left ventricular focal block. Amer. F. Cardiol., 18, 705.

Entman, M. L., Estes, E. H., and Hackel, D. B. (1967). The pathologic basis of the electrocardiographic pattern of parietal block. Amer. Heart f., 74, 202.

Grant, R. P. (1956). Left axis deviation: an electrocardiographic-pathologic correlation study. Circulation, 14, 233.

(1957). Clinical Electrocardiography. McGraw-Hill, New York.

Grishman, A., and Scherlis, L. (1952). Spatial Vectorcardiography. W. B. Saunders, Philadelphia.

Kulbertus, H., Coyne, J., and Hallidie-Smith, K. A. (1968). Left axis deviation with right bundle-branch block in ventricular septal defect before and after surgical closure. In Proceedings of the British Cardiac Society. Brit. Heart $\mathcal{F}$., 30, 422.

Lasser, R. P., Haft, J. I., and Friedberg, C. K. (1968). Relationship of right bundle-branch block with marked left axis deviation (with left parietal or peri-infarction block) to complete heart block and syncope. Circulation, 37, 429.

Lenègre, J. (1957). Contribution à l'étude des blocs de branche. Arch. Mal. Coeur, Suppl. 1.

Lepeschkin, E. (1964). The electrocardiographic diagnosis of bilateral bundle-branch block in relation to heart block. Progr. cardiovasc. Dis., 6, 445.

Lev, M. (1957). The conduction system in the human heart. Milit. Med., 120, 262.

- (1964). The normal anatomy of the conduction system in man and its pathology in atrioventricular block. Ann. N.Y. Acad. Sci., 111, 817.

Pryor, R., and Blount, S. G. (1966). The clinical significance of true left axis deviation-left intraventricular blocks. Amer. Heart F., 72, 391.

Saltzman, P., Linn, H., and Pick, A. (1966). Right bundlebranch block with left axis deviation. Brit. Heart $\mathcal{F}$., 28, 703.

Slama, R., Marneffe, H., Gourgon, R., and Motte, G. (1966). Aspect du ventriculogramme en rhythme sinusal chez les malades atteints de blocs auriculoventriculaires chroniques. Mal. cardiovasc., 7, 353.

Sodi-Pallares, D., Cisneros, F., Medrano, Ga., Bisteni, A., Testelli, M. R., and de Micheli, A. (1963). Electrocardiographic diagnosis of myocardial infarction in the 
presence of bundle-branch block (right and left), ventricular premature beats and Wolff-Parkinson-White syndrome. Progr. cardiovasc. Dis., 6, 107.

Spach, M. S., Huang, S., Armstrong, S. I., and Canent, R. V. (1963). Demonstration of peripheral conduction system in human hearts. Circulation, 28, 333.

Uhley, H. N., and Rivkin, L. M. (1959). Visualization of the left branch of the human atrioventricular bundle. Circulation, 20, 419.

ing interruption of the main and peripheral branches of the canine left bundle of His. Amer. F. Cardiol., 13, 41.
Unger, P. N., Lesser, M. E., Kugel, V. H., and Lev, M. (1958). The concept of "masquerading" bundlebranch block. Circulation, 17, 397.

van Bogaert, A. (1967). Valeur clinique de la sinistrodéviation de l'axe électrique dans le plan des déviations standard. Arch. Mal. Coeur, 60, 337.

Watt, T. B., Freud, G. E., Durrer, D., and Pruitt, R. D. (1968). Left anterior arborization block combined with right bundle-branch block in canine and primate hearts. Circulat. Res., $22,57$.

- , and Pruitt, R. D. (1965). Electrocardiographic findings associated with experimental arborization block in dogs. Amer. Heart f., 69, 642 . 